\title{
PENGUKURAN TINGKAT DUKUNGAN TEKNOLOGI INFORMASI PADA DIREKTORAT TRANSFORMASI TEKNOLOGI KOMUNIKASI DAN INFORMASI, DIREKTORAT JENDERAL PAJAK DENGAN MENGGUNAKAN IT BALANCED SCORECARD
}

\author{
Achmad Nizar Hidayanto, Yudhiansyah Ahmadin, dan Meganingrum Arista Jiwanggi
}

Fakultas Ilmu Komputer, Universitas Indonesia, Kampus Baru UI Depok, Jawa Barat, 16424, Indonesia

E-mail: nizar@cs.ui.ac.id

\begin{abstract}
Abstrak
Direktorat Transformasi Teknologi Komunikasi dan Informasi (Direktorat TTKI) mengemban tugas dalam mewujudkan rencana strategis Direktorat Jenderal Pajak melalui modernisasi information system (IS) atau information technology (IT) secara efisien dan optimal. Untuk menilai tingkat efisiensi dan optimalisasi penggunaan information technology (IT), diperlukan proses pengukuran secara berkesinambungan. Pada penelitian ini akan dilakukan pengukuran tingkat dukungan SI/TI pada Direktorat TTKI, sehingga Direktorat TTKI bisa memperbaiki hal-hal yang dianggap masih lemah. Instrumen yang digunakan adalah IT Balanced Scorecard yang dikembangkan oleh Grembergen berdasarkan konsep Balanced Scorecard. Selain itu, digunakan pula indikator yang diperoleh dari US Governance Accountability Office (US GAO). Indikator-indikator inilah yang kemudian dijadikan bahan untuk menilai tingkat dukungan IT yang dilakukan dengan menyebarkan kuesioner ke staff Direktorat TTKI. Berdasarkan hasil pengukuran IT Balanced Scorecard yang dilakukan didapatkan hasil bahwa tingkat dukungan IT pada Direktorat Transformasi Teknologi Komunikasi dan Informasi pada perspektif kontribusi perusahaan sebesar $49 \%$, perspektif orientasi pengguna sebesar $66.3 \%$, perspektif penyempurnaan organisasi sebesar $68.3 \%$, dan perspektif orientasi masa depan sebesar $25.6 \%$.
\end{abstract}

Kata Kunci: teknologi informasi, pengukuran dukungan IS/IT, IT balanced scorecard, US GAO

\begin{abstract}
Directorate of Communications and Information Technology Transformation took on the task in realizing the strategic plan of the Directorate General of Taxation through the modernization of IS / IT efficiently and optimally. To assess the efficiency and optimizing the use of IT, required continuous measurement process. In this study the level of support of IS / IT Directorate TTKI will be measured, so Directorate TTKI can fix things that were deemed to be weak. The instrument used is the IT Balanced Scorecard, developed by Grembergen based on the concept of Balanced Scorecard. In addition, the indicators used are obtained from the U.S. Governance Accountability Office (U.S. GAO). These indicators are then used as material to assess the level of IT support is done by distributing questionnaires to the staff of the Directorate TTKI. Based on the IT Balanced Scorecard measurements, showed that the level of IT support to the Directorate of Communications and Information Technology Transformation at perspective on the company's contribution is 49\%, useroriented perspective is $66.3 \%$, organization's improvement perspective is $68.3 \%$, and the futureorientated perspective is $25.6 \%$.
\end{abstract}

Keywords: information technology, measuring support for IS / IT, IT balanced scorecard, the US GAO

\section{Pendahuluan}

Kondisi sosial, politik, dan ekonomi Indonesia telah berkembang sangat cepat. Kini mulai bermunculan berbagai tuntutan pada lembaga pemerintahan, termasuk Direktorat Jenderal Pajak. Tuntutan yang muncul antara lain seperti tuntutan akuntabilitas, upaya penegakan hukum perpajakan, pemulihan perekonomian, dan kemandirian pembiayaan negara. Tuntutan ini muncul mengingat pentingnya peranan penerimaan pajak sebagai dasar mewujudkan kemandirian pembiayaan negara dan dapat memengaruhi keberhasilan pemerintah dalam memulihkan kondisi ekonomi.

Sementara itu, sistem informasi merupakan sarana dasar yang sangat vital untuk mendukung proses bisnis utama dan memberikan pelayanan prima kepada para konsumen, dalam hal ini para wajib pajak. Keberhasilan di dalam memanfaatkan teknologi informasi dan komunikasi mutakhir untuk membangun sistem 
informasi dan prosedur kerja standar (standard operating procedure) merupakan keharusan bagi Direktorat Jenderal Pajak untuk dapat menyelenggarakan sistem dan manajemen perpajakan kelas dunia dan menjadi model pelayanan yang dipercaya dan dibanggakan masyarakat. Proses modernisasi dan pembangunan sistem informasi tersebut harus dilakukan melalui perencanaan, desain yang cermat, serta pemilihan teknologi yang tepat guna. Sebagaimana yang telah tertuang didalam rencana strategis yang telah dimiliki oleh Direktorat Jenderal Pajak, dalam salah satu tujuannya dinyatakan perlunya melaksanakan modernisasi teknologi komunikasi dan informasi secara efektif dan efisien.

Secara umum, beberapa core system yang masih berjalan di Direktorat Jenderal Pajak seperti Sistem Informasi Perpajakan, Sistem Administrasi Pajak Terpadu, dan Sistem Informasi Direktorat Pajak, masih berjalan secara paralel serta memiliki platform infrastruktur yang berbeda dan belum terintegrasi sepenuhnya. Dengan adanya masalah tersebut, dikhawatirkan akan menyebabkan tujuan organisasi yang telah dituangkan dalam strategi organisasi akan sulit tercapai, terutama hal-hal yang berhubungan dengan dukungan teknologi informasi. Untuk itu perlu dilakukan pengukuran terhadap dukungan IT pada Direktorat Transformasi Teknologi Komunikasi dan Informasi (Direktorat TTKI), terhadap rencana strategis Direktorat Jenderal Pajak.

Beberapa penelitian yang terkait dengan topik paper ini pernah dilakukan sebelumya dan rangkumannya dapat dilihat pada tabel I. Penelitian oleh Purnomo membangun sebuah IT Balanced Scorecard sebagai dasar pengukuran tingkat dukungan divisi IT dalam sebuah lembaga pendidikan. Hal yang menjadi kesamaan antara penelitian ini dengan penelitian Purnomo adalah penggunaan IT Balanced Scorecard sebagai alat untuk pengukuran tingkat dukungan dan pembobotan penilaian yang digunakan dalam penelitian [1]. Penelitian oleh Robbi yang menilai tingkat kematangan keselarasan strategi IS/IT terhadap strategi organisasi di POLDA Kalimantan Selatan mengacu pada IT Balanced Scorecard dan Maturity Model COBIT 4.1. [2]. Penelitian oleh Kelana melakukan pengukuran kinerja Implementasi Aplikasi menggunakan IT
Balanced Scorecard dalam mengukur hasil dan kinerja proses pengembangan IT [3]. Penelitian oleh Hartawan menghasilkan model integrasi $I T$ Balanced Scorecard dan Six Sigma untuk meningkatkan pengelolaan Divisi Teknologi Informasi pada PT XYZ dan pengukuran kinerja secara komprehensif dan seimbang [4]. Penelitian oleh Prasetya melakukan pengukuran kinerja manajemen pengembangan aplikasi IT. Prasetya menggunakan metodologi IT Balanced Scorecard sebagai alat ukur utama dalam pengukuran kinerja manajemen dan framework COBIT dan ITIL sebagai tambahan pengukuran [5]. Kemiripan yang dimiliki keempat penelitian tersebut dengan penelitian ini adalah penggunaan fungsi IT Balanced Scorecard sebagai alat untuk mengukur kinerja IT.

Matriks Portofolio, teori McFarlan dan McKenney mengklasifikasikan teknologi informasi berdasarkan aspek Business Functionality Dependent Upon IT dan aspek IT Development for Competitive Advantage sehingga terdapat empat tipe peranan yaitu Strategic, High Potential, Key Operational, dan Support seperti terlihat dalam gambar 1 [6].

\begin{tabular}{|c|c|}
\hline STRATEGIC & HIGH POTENTIAL \\
\hline $\begin{array}{l}\text { Application that are critical } \\
\text { to sustaining future } \\
\text { business strategic }\end{array}$ & $\begin{array}{l}\text { Application that may be } \\
\text { important in achieving future } \\
\text { success }\end{array}$ \\
\hline $\begin{array}{l}\text { Application on which the } \\
\text { organization currently } \\
\text { depends for success }\end{array}$ & $\begin{array}{l}\text { Application that are } \\
\text { valueable but not critical to } \\
\text { success }\end{array}$ \\
\hline KEY OPERATIONAL & SUPPORT \\
\hline
\end{tabular}

Gambar 1. Application portfolio McFarlan.

IT Balanced Scorecard, pada tahun 1997, Van Grembergen dan Van Bruggen mengadopsi Balanced Scorecard (BSC) untuk digunakan pada Departemen Teknologi Informasi [7]. Tujuan IT Balanced Scorecard adalah memungkinkan para pengguna untuk menyesuaikan perencanaan dan aktivitas-aktivitas sistem informasi dengan tujuan dan kebutuhan organisasi, menyesuaikan usaha pegawai dengan tujuan sistem informasi, menyediakan pengukuran untuk mengevaluasi efektivitas organisasi sistem informasi, mendorong dan mempertahankan kinerja sistem informasi yang semakin meningkat, dan pencapaian hasil yang seimbang di antara kelompok stakeholder. 


\begin{tabular}{|c|c|}
\hline USER ORIENTATION & BUSINESS CONTRIBUTION \\
\hline $\begin{array}{l}\text { How do users view the IT department? } \\
\text { Mission } \\
\text { To be the preferred supplier of information systems. } \\
\text { Objectives } \\
\text { - Preferred supplier of applications } \\
\text { - Preffered supplier of operations vs proposer of best solution, } \\
\text { from whatever source } \\
\text { - Partnership with users } \\
\text { - User satisfaction }\end{array}$ & $\begin{array}{l}\text { How does management view the IT department? } \\
\text { Mission } \\
\text { To obtain a reasonable business contribution from IT } \\
\text { investments. } \\
\text { Objectives } \\
\text { - Control of IT expenses } \\
\text { - Business value of IT projects } \\
\text { - Provision of new business capabilities }\end{array}$ \\
\hline OPERATIONAL EXCELLENCE & FUTURE ORIENTATION \\
\hline $\begin{array}{l}\text { How effective and efficient are the IT processes? } \\
\text { Mission } \\
\text { To deliver effective and efficient IT applications and services. } \\
\text { Objectives } \\
\text { - Efficient and effective developments } \\
\text { - Efficient and effective operations }\end{array}$ & $\begin{array}{l}\text { How well is IT positioned to meet future needs? } \\
\text { Missions } \\
\text { To develop opportunities to answer future challenges. } \\
\text { Objectives } \\
\text { - Training and education of IT staff } \\
\text { - Expertise of IT staff } \\
\text { - Research into emerging technologies } \\
\text { - Age of application portfolio }\end{array}$ \\
\hline
\end{tabular}

Gambar 2. Perspektif dalam IT Balance Scorecard.

TABEL I

RANGKUMAN PENELITIAN TERKAIT

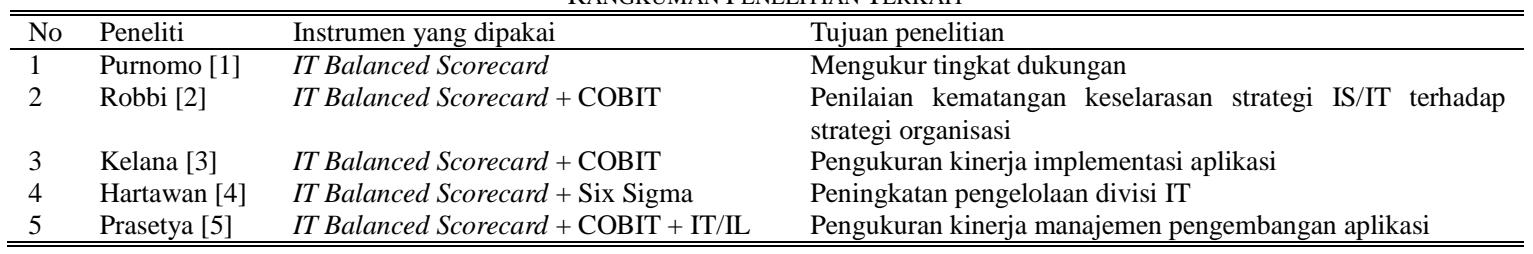

Gambar 2 menjelaskan keempat perspektif dalam IT Balanced Scorecard. Pengukuran Kontribusi Kepada Organisasi, perspektif business contribution adalah perspektif yang mengevaluasi kinerja IT berdasarkan pandangan dari manajemen eksekutif. Evaluasi IT dapat dipisahkan menjadi dua macam yaitu jangka pendek berupa evaluasi secara financial dan jangka panjang yang berorientasi pada proyek dan fungsi IT itu sendiri. Pengukuran Orientasi Pengguna, perspektif user orientation adalah perspektif yang mengevaluasi kinerja IT berdasarkan cara pandang pengguna bisnis (pelanggan) dan lebih jauh lagi adalah pelanggan dari unit bisnis yang ada. Dalam perspektif ini organisasi melakukan identifikasi pelanggan dan segmen pasar yang akan dimasuki. Dengan perspektif orientasi pengguna ini, organisasi dapat menyelaraskan berbagai ukuran pelanggan penting yaitu: kepuasan, loyalitas, retensi, akuisisi, dan profitabilitas, dengan pelanggan sendiri dan segmen pasar sasaran. Selain itu perspektif ini juga memungkinkan organisasi melakukan identifikasi dan pengukuran di mana secara eksplisit menetapkan proposisi nilai (faktor pendorong) yang akan organisasi berikan kepada pelanggan dan pasar sasaran. Pengukuran Kesempurnaan Operasi. Perspektif operational excellence adalah perspektif yang menilai kinerja IT berdasarkan cara pandang manajemen IT termasuk pihak-pihak yang berkaitan dengan audit dan pihak yang menetapkan aturan-aturan yang digunakan. Pengukuran Orientasi Masa Depan, perspektif future orientation adalah perspektif yang menilai kinerja IT berdasarkan cara pandang dari departemen itu sendiri, yaitu pelaksanaan, para praktisi dan profesional yang ada. Perspektif ini akan menyiapkan infrastruktur organisasi yang memungkinkan tujuan-tujuan dalam tiga perspektif lainnya dapat dicapai. Kemampuan organisasi untuk dapat menghasilkan produk atau jasa di masa mendatang dengan kemampuan layanan yang memuaskan harus dipersiapkan mulai dari saat ini. Pihak manajemen harus dapat memerkirakan tren di masa mendatang dan membuat langkah-langkah persiapan dalam mengantisipasinya.

Pada bulan Maret 1988, US Governance Accountability Office mengeluarkan artikel tentang pengukuran performa IT yang memiliki empat perspektif [8], strategis, pengguna, bisnis internal, serta inovasi dan pembelajaran. Pada perspektif strategis IT terdapat empat objective yaitu tujuan misi perusahaan, manajemen dan analisis portofolio, kinerja finansial dan investasi, dan penggunaan sumber daya IT. Kemudian pada perspektif pengguna IT terdapat tiga objective yaitu kerja sama dan keterlibatan pengguna, kepuasan pengguna, dan dukungan proses bisnis. Sementara pada perspektif bisnis internal IT 
terdapat empat objective, yaitu perawatan dan pengembangan aplikasi, kinerja proyek, ketersediaan infrastruktur, dan pelaksanaan standar arsitektur perusahaan. Terakhir, dalam perspektif inovasi dan pembelajaran IT terdapat empat objective yaitu pengembangan dan kompetensi tenaga kerja, penggunaan teknologi maju, metodologi yang dipakai, dan referensi kepuasan staf.

\section{Metodologi}

Kerangka penelitian, pertama, dilakukan penurunan visi dan misi IT hingga menjadi strategi IT. Setelah itu dilakukan pembuatan portofolio aplikasi yang dibutuhkan dalam pembuatan IT Strategic Grid. Setelah strategi IT selesai dibuat, dilakukan penyusunan IT Balanced Scorecard. Dari empat hal yang seharusnya dihasilkan dan relevan dengan penelitian ini hanyalah ukuran strategis dan tujuan strategis. Hal ini disebabkan karena kedua hal tersebut yang dibutuhkan untuk menjalankan IT Balanced Scorecard sebagai fungsi pengukuran. Selain itu, digunakan juga instrumen tambahan dari US GAO untuk membuat ukuran strategis dalam beberapa tujuan strategis. Teknik ini juga digunakan oleh Purnomo dalam mengukur tingkat dukungan divisi IT di sebuah lembaga pendidikan [1].

Tahapan penelitian, dalam penelitian untuk mengukur tingkat dukungan ini, terdapat tujuh tahapan yang dilakukan. Pertama adalah perumusan masalah. Pada tahapan ini dilakukan penggalian masalah-masalah yang dihadapi oleh Direktorat TTKI. Kedua adalah studi literatur. Peneliti melakukan kajian literatur untuk mengkaji beberapa instrumen yang bisa dipergunakan sebagai sarana untuk membantu memecahkan permasalahan penelitian. Kemudian ketiga adalahpemilihan framework. IT Balanced Scorecard dianggap paling sesuai untuk memecahkan permasalahan yang dihadapi. Peneliti juga menggunakan beberapa instrumen pendukung seperti US GAO serta IT Strategic Grid McFarlan., dan menggunakan cause effect analysis dalam pembuatan IT Balanced Scorecard.

Tahapan selanjutnya adalah membuat desain kuesioner. Pertanyaan kuesioner dibangun dari ukuran strategis dari hasil penyusunan IT Balanced Scorecard yang dilengkapi dengan panduan dari US GAO dan dibuat dengan menggunakan skala Likert dengan skala 1 - 5 . Kelima, Pengumpulan Data. Peneliti melakukan pengumpulkan data dengan menggunakan data primer dan data sekunder. Data primer diperoleh dengan menyebar kuesioner dan melakukan observasi. Data sekunder diperoleh dengan mempelajari dokumentasi proyek IT yang telah selesai, dokumen kepegawaian, dokumen anggaran operasional Direktorat TTKI, serta dokumen sistem monitoring internal aplikasi dan perangkat keras. Direktorat TTKI memiliki pegawai sebanyak 100 orang, mulai dari Eselon II sampai dengan level staf. Peneliti menyebarkan kuesioner terhadap 25 orang responden secara acak. Kuesioner tidak dilakukan pada manajemen puncak Direktorat TTKI. Dari 25 kuesioner yang disebar, peneliti mendapatkan feedback dari 20 responden. Pemilihan pertanyaan kuesioner pada penelitian ini dilakukan berdasarkan penelitian yang dilakukan oleh Purnomo [1], dengan tambahan pengukuran strategis dari US GAO. Pada dasarnya, yang ingin digali dari kuesioner ini meliputi keempat perspektif dari IT Balanced Scorecard. Tahapan keenam adalah melakukan analisis hasil penelitian. Setelah kuesioner didapatkan, peneliti melakukan tabulasi dan hasilnya dianalisis. Kemudian yang terakhir adalah membuat kesimpulan dan rekomendasi. Kesimpulan didapatkan berdasarkan dari analisis hasil pengukuran. Saran akan diberikan dengan melihat kaitan hasil penelitian untuk meningkatkan tingkat dukungan IT pada Direktorat Jenderal Pajak.

\section{Analisis dan Pembahasan}

Perumusan Visi, Misi, dan Strategi IT Direktorat TTKI. Langkah pertama adalah melakukan penyelarasan visi dan misi ke strategi IT. Visi Direktorat Jenderal Pajak adalah menjadi institusi pemerintah yang menyelenggarakan sistem administrasi perpajakan modern yang efektif, efisien, dan dipercaya masyarakat dengan integritas dan profesionalisme yang tinggi. Misinya adalah menghimpun penerimaan pajak negara berdasarkan Undang-undang Perpajakan yang mampu mewujudkan kemandirian pembiayaan APBN melalui sistem administrasi perpajakan yang efektif dan efisien. Terdapat lima strategi yang dimiliki Direktorat TTKI. (1) Menghimpun Penerimaan Dalam Negeri dari sektor pajak yang mampu menunjang kemandirian pembiayaan pemerintah berdasarkan UU Perpajakan dengan tingkat efektivitas dan efisiensi yang tinggi. (2) Mendukung kebijaksanaan Pemerintah dalam mengatasi permasalahaan ekonomi bangsa dengan kebijaksanaan perpajakan yang minimizing distortion tetapi justru meningkatkan pertumbuhan ekonomi. (3) Mendukung proses otonomi dan perimbangan keuangan pusat dan daerah dalam rangka proses demokratisasi bangsa. (4) Senantiasa memperbarui diri, selaras dengan 
aspirasi masyarakat dan teknokrasi perpajakan serta administrasi perpajakan mutakhir. (5) Memberikan pelayanan profesional kepada wajib pajak agar dapat menjalankan urusan perpajakan dengan mudah, cepat, nyaman, dan murah.

Berdasarkan visi dan misi di atas, dilakukan perumusan visi, misi, dan strategi IT. Visi IT adalah pembangunan sistem informasi Terpadu dengan menggunakan teknologi tepat guna dan $u p$ to date, menghasilkan informasi berkualitas dan merupakan sarana pendukung keberhasilan dalam mencapai kesempurnaan kegiatan pelayanan, operasional dan manajemen Direktorat Jenderal Pajak. Misi IT adalah menjalankan fungsi peranan dan tanggung jawab dari sistem informasi sebagaimana digariskan oleh Direktorat Jenderal Pajak yang meliputi pengolahan data elektronik, layanan dan dukungan teknologi informasi, dan manajemen sistem informasi.

Terdapat beberapa strategi IT. (1) Mengembangkan organisasi dan menyempurnakan Sistem Informasi untuk meningkatkan keabsahan, konsistensi, keamanan, dan kemutakhiran data perpajakan. (2) Memberikan fasilitas pelayanan elektronik untuk memudahkan wajib pajak dalam rangka melaksanakan hak dan kewajiban perpajakannya. (3) Melengkapi dan menyempurnakan sistem informasi yang diperlukan organisasi Direktorat Jenderal Pajak didalam menjalankan tugasnya. (4) Menyediakan informasi yang berkualitas (tepat waktu, akurat, absah) untuk melayani kebutuhan informasi manajemen Direktorat Jenderal Pajak.

Langkah kedua adalah melakukan perumusan hubungan sebab akibat. Untuk membangun hubungan sebab akibat, digunakan model standar dari IT Balanced Scorecard [9]. Agar personil Direktorat TTKI mendapatkan keahlian strategis dalam pengembangan dan perawatan aplikasi dan infrastuktur yang digunakan oleh Direktorat Jenderal Pajak, perlu dipersiapkan pelatihan dan penelitian terhadap teknologi terbaru secara intensif. Keahlian strategis tersebut akan memengaruhi efisiensi transformasi teknologi, waktu, dan sumber daya dalam pengembangan dan perawatan layanan IT, juga akan meningkatkan kecepatan proses komputasi dengan menerapkan teknologi yang tepat guna.

Langkah ketiga adalah dengan merumuskan arsitektur Sistem Informasi yang dibutuhkan oleh Direktorat TTKI. Arsitektur sistem informasi ini memberikan gambaran mengenai sistem informasi yang dibutuhkan oleh Direktorat TTKI untuk mencapai visi dan misinya. Tabel II memberikan gambaran mengenai arsitektur sistem informasi perpajakan.

Langkah keempat adalah menyusun IT Strategic Grid berdasarkan tabel II untuk Direktorat TTKI seperti yang dapat dilihat pada tabel III. Penyusunan IT Strategic Grid bertujuan untuk mengelompokkan aplikasi ke dalam keempat kuadran McFarlan. Dari kuadran McFarlan tersebut, bisa dilihat manakah yang termasuk dalam kuadran strategis sehingga bisa dihitung besar persentase aplikasi yang masuk ke dalam kuadran strategis sebagai salah satu ukuran strategis yang digunakan pada pengukuran tingkat dukungan TI. IT Strategic Grid disusun dengan menggunakan teori McFarlan \& McKenney [6]. Langkah berikutnya, berdasarkan analisis hubungan sebab akibat di atas, peneliti merangkum tujuan strategis untuk masing-masing perspektif dalam IT Balanced Scorecard pada tabel IV. Langkah berikutnya adalah menentukan ukuran strategis pada tiap-tiap tujuan strategis dan pemetaan ukuran strategis yang digunakan dari US GAO. Ukuran strategis yang akan digunakan sebagian besar diambil dari IT Balanced Scorecard dengan beberapa tambahan dari US GAO [7][8]. Hasil pemetaan ukuran strategis yang digunakan dari US GAO menjadi dasar peneliti dalam melakukan proses penyusunan instrumen penelitian maupun pengumpulan data, baik melalui kuesioner maupun pengumpulan data sekunder lainnya.

Pengukuran Tingkat Dukungan IT Menggunakan IT Balanced Scorecard. Terdapat empat perspektif yaitu kontribusi perusahaan, orientasi pengguna, penyempurnaan operasional, dan orientasi masa depan. Kontribusi Perusahaan, tujuan strategis pertama pada perspektif ini adalah nilai bisnis fungsi IT. Berdasarkan data IT Strategic Grid di atas, tidak ada aplikasi yang masuk pada kuadran strategis sehingga disimpulkan bahwa persentase kapasitas pengembangan untuk memenuhi proyek strategis adalah sebesar 0\%. Tujuan strategis kedua adalah pengendalian biaya IT. Ukuran yang digunakan pada tujuan ini adalah persentase penyimpangan terhadap anggaran IT. Dari hasil penelusuran terhadap 30 dokumen proyek IT pada tahun anggaran 2009, terdapat tiga proyek IT yang biayanya di bawah dari yang sudah dianggarkan, sedangkan 27 proyek lain tepat waktu dan tepat anggaran sehingga dapat disimpulkan bahwa terdapat $10 \%$ penyimpangan terhadap anggaran IT. 
TABEL II

TABEL ARSITEKTUR SISTEM INFORMASI PERPAJAKAN

\begin{tabular}{|c|c|}
\hline Nama Aplikasi & Fungsionalitas \\
\hline e-Registration & Sistem pendaftaran wajib pajak secara online untuk mempermudah mendapatkan NPWP. \\
\hline e-Portal & Sistem informasi yang memberikan petunjuk praktis terhadap permasalahan pajak. \\
\hline Sistem Pemeriksaan & Sistem mampu mengotomatisasi proses pemeriksaan pajak seperti Aplikasi Penerbitan Lembar \\
\hline Pajak & $\begin{array}{l}\text { Penugasan Pemeriksaan, Aplikasi Kepegawaian, Aplikasi Surat Perintah, Aplikasi Perhitungan, } \\
\text { Angka Kredit, Aplikasi Surat Masuk dan Keluar }\end{array}$ \\
\hline $\begin{array}{l}\text { Sistem Informasi Pajak/ } \\
\text { Sistem Informasi }\end{array}$ & $\begin{array}{l}\text { Sistem informasi yang memudahkan wajib pajak dalam berinteraksi dengan kantor pajak yang } \\
\text { meliputi pendaftaran, pembayaran, dan pelaporan pajak. Mampu mengawasi setiap kewajiban dari }\end{array}$ \\
\hline Direktorat Jenderal Pajak & $\begin{array}{l}\text { tiap wajib pajak, karena mampu memberikan peringatan secara otomatis jika wajib pajak terlambat } \\
\text { atau kurang bayar pajak. }\end{array}$ \\
\hline e-filling & Sistem penyampaian Surat Pemberitahuan Pajak secara online \\
\hline $\begin{array}{l}\text { Monitoring Pelaporan dan } \\
\text { Pembayaran Pajak }\end{array}$ & Me-monitor dan mengawasi penerimaan pajak secara online \\
\hline $\begin{array}{l}\text { Sistem Informasi } \\
\text { Kepegawaian }\end{array}$ & Aplikasi pendukung mengenai kepegawaian Direktorat Jenderal Pajak. \\
\hline $\begin{array}{l}\text { Sistem Otomasi Aplikasi } \\
\text { Perkantoran }\end{array}$ & $\begin{array}{l}\text { Aplikasi pendukung internal untuk keperluan otomatisasi perkantoran di lingkungan Direktorat } \\
\text { Jenderal Pajak. }\end{array}$ \\
\hline
\end{tabular}

TABEL III

IT STRATEGIC GRID DIREKTORAT TTKI

\begin{tabular}{cc}
\hline \hline \multicolumn{1}{c}{ Strategic } & \multicolumn{1}{c}{ High Potential } \\
\hline Key Operational & Support \\
• Sistem Informasi & $\bullet$ e-Registration. \\
Pajak & $\bullet$ e-Portal. \\
•Sistem Informasi & -Sistem Informasi Kepegawaian. \\
Direktorat Jenderal & $\bullet$ Sistem Otomasi Aplikasi \\
Pajak. & Perkantoran. \\
& •Sistem Pemeriksaan Pajak \\
\hline \hline
\end{tabular}

TABEL IV

IT BALANCED SCORECARD TTKI

\begin{tabular}{ll}
\hline \hline \multicolumn{1}{c}{ Orientasi Pengguna } & \multicolumn{1}{c}{ Kontribusi Perusahaan } \\
\hline - Kualitas Produk & • Nilai bisnis fungsi IT \\
- Efektifitas Produk & • Pengendalian biaya IT \\
- Kepuasan Pengguna & - Pemanfaatan asset \\
\hline $\begin{array}{l}\text { Penyempurnaan } \\
\text { Operasional }\end{array}$ & Orientasi Masa Depan \\
\hline - Efisiensi & - Pelayanan tetap personil IT \\
$\begin{array}{l}\text { pengembangan } \\
\text { aplikasi }\end{array}$ & - Keahlian personil IT \\
- Efisiensi proses & - Penelitian terhadap teknologi \\
komputasi & yang sedang berkembang \\
- Efisiensi Fungsi Layana & \\
\hline \hline
\end{tabular}

Tujuan strategis ketiga adalah pemanfaatan asset. Untuk menilai tingkat dukungan pada tujuan strategis ini digunakan tiga ukuran strategis. Terdapat tiga hasil pengukuran terhadap ketiga ukuran strategis tersebut yang dilakukan melalui observasi langsung dalam rentang waktu Januari 2010-April 2010.(1) Persentase sumber daya terpakai bersama antar unit rata-rata sebesar $55 \%$. Asumsi sumber daya disini adalah server dan printer. Dari hasil observasi didapatkan data bahwa $100 \%$ server dapat digunakan secara bersama dan hanya $10 \%$ printer yang digunakan secara bersama. (2) Persentase basis data dan aplikasi terpakai bersama antar unit adalah $100 \%$. (3) Persentase perangkat keras dan lunak dengan kemampuan interoperability adalah $100 \%$.

Orientasi Pengguna, tujuan strategis pertama pada perspektif ini adalah kualitas produk. Penilaian dilakukan dengan mengukur persentase tingkat kemudahan penggunaan aplikasi. Data diperoleh dengan kuisioner. Hasil pengukuran menunjukan indeks kemudahan aplikasi sebesar $77,1 \%$.

Tujuan strategis berikutnya adalah efektivitas produk. Untuk mengukur tingkat dukungan IT pada tujuan strategis ini digunakan tiga ukuran strategis. Terdapat tiga hasil pengukuran ketiga ukuran strategis tersebut. (1) Persentase proses otomatis dengan proses manual yang didapatkan dari kuesioner menunjukkan angka sebesar $62,2 \%$. Persentase ini menunjukkan seberapa besar aplikasi dapat mempercepat pekerjaan dibandingkan secara manual. (2) Index fungsional aplikasi menunjukan angka sebesar $68,8 \%$. Ukuran strategis ini untuk mengukur seberapa besar tingkat fungsionalitas dari sebuah aplikasi. Data didapatkan melalui kuesioner. (3) Persentase pelatihan aplikasi IT baru terhadap pengguna adalah $100 \%$. Data ini diperkuat dengan temuan dalam setiap dokumen proyek yang mewajibkan pihak ketiga untuk memberikan pelatihan sebelum pengguna menggunakan sebuah aplikasi baru.

Tujuan strategis terakhir adalah kepuasan pengguna. Untuk mengukur tingkat dukungan IT pada tujuan strategis ini digunakan empat ukuran strategis. Berikut ini merupakan hasil pengukuran untuk empat ukuran strategis tersebut yang didapatkan melalui kuesioner, yaitu: (a) Persentase kepuasan pengguna terhadap hasil produk IT adalah sebesar $67.8 \%$. (b) Persentase kepuasan pengguna terhadap pemecahan masalah IT adalah sebesar 69\%. (c) Persentase kepuasan pengguna terhadap dukungan dan layanan IT adalah sebesar $69.1 \%$. (d) Persentase kepuasan pengguna terhadap pelatihan IT adalah sebesar $76.8 \%$.

Penyempurnaan Operasional, tujuan strategis pertama pada perspektif ini adalah efisiensi pengembangan aplikasi. Untuk mengukur tingkat 
dukungan IT pada tujuan strategis ini digunakan tiga ukuran strategis. Terdapat tiga hasil pengukuran terhadap tiga ukuran strategis tersebut yang dilakukan melalui observasi langsung dalam rentang waktu Januari 2010-April 2010. (1) Ratarata peningkatan biaya di luar anggaran adalah sebesar 3\%. Maksud dari ukuran strategis ini adalah untuk mengukur berapa banyak proyek IT yang terlambat dari jadwal. Dari hasil pendalaman dokumen proyek IT didapatkan bahwa hanya satu proyek dari total 30 proyek IT pada tahun anggaran 2009 terlambat dari jadwal. (2) Persentase proyek yang dijalankan menggunakan SLA (Service Level Agreement) adalah 100\%. (3) Indeks keterlibatan pengguna dalam pembangunan aplikasi adalah 59.6\%. Data ini didapat berdasarkan hasil dari kuesioner.

Tujuan strategis kedua adalah efisiensi proses komputasi. Untuk mengukur tingkat dukungan IT pada tujuan strategis ini digunakan lima ukuran stategis. Terdapat lima hasil pengukuran terhadap lima ukuran strategis tersebut yang dilakukan melalui observasi langsung dan kuesioner dalam rentang waktu Januari 2010-April 2010. (1) Persentase ketersediaan server adalah 99\%. Data ini didapatkan dari hasil observasi langsung dan pendalaman log server. (2) Persentase ketersediaan jaringan adalah $95 \%$. Dalam rentang waktu penelitian, Direktorat Jenderal Pajak sedang melakukan instalasi infrastruktur baru pada gedung baru, sehingga menyebabkan penurunan tingkat ketersediaan jaringan seperti yang tertangkap pada saat observasi langsung dan perhitungan jumlah komplain (spesifik pada masalah jaringan). Data didapatkan berdasarkan observasi langsung dan log komplain pada waktu penelitian. (3) Persentase ketersediaan aplikasi adalah $97.5 \%$. Hasil ini merupakan rata-rata persentase ketersedian aplikasi dan server dengan asumsi ketersediaan aplikasi bergantung kepada ketersediaan server dan ketersediaan jaringan. (4) Rata-rata waktu tanggap aplikasi setiap pengguna adalah 69.5\%. Data diperoleh melalui kuesioner. (5) Persentase waktu proses yang cepat, dengan asumsi waktu proses yang dianggap cepat 30 menit-1 jam terhadap waktu proses rata-rata, adalah $88.8 \%$.

Tujuan strategis ketiga adalah efisiensi fungsi layanan. Untuk mengukur tingkat dukungan IT pada tujuan strategis ini digunakan tiga ukuran strategis. Terdapat tiga hasil pengukuran terhadap tiga ukuran strategis tersebut yang didapatkan melalui kuesioner. (1) Persentase aktivitas perawatan adalah $30.2 \%$. Ukuran strategis ini bertujuan untuk mengetahui seberapa sering dilakukannya pengecekan data dari aplikasi (validasi/verifikasi) pada suatu periode tertentu. Berdasarkan data hasil kuesioner di atas, rata-rata pengecekan dilakukan sekali dalam satu bulan. (2) Rata-rata waktu perbaikan masalah oleh personil IT adalah $40 \%$ yaitu sekitar 1-2 hari. (3) Persentase masalah terpecahkan secara cepat ratarata sebesar $69.7 \%$. Rata-rata $50 \%$ - $75 \%$ masalah dapat diselesaikan dalam waktu 1-2 jam.

Orientasi Masa Depan, tujuan strategis pertama adalah pelatihan tetap untuk personil IT. Untuk mengukur tingkat dukungan IT pada tujuan strategis ini digunakan dua ukuran strategis. Terdapat dua hasil pengukuran terhadap dua ukuran strategis tersebut yang dilakukan melalui observasi langsung dan pendalaman dokumen yang dimiliki oleh Direktorat Jenderal Pajak dalam rentang waktu Januari 2010-April 2010. (1) Persentase anggaran IT yang digunakan untuk pelatihan adalah $0.2 \%$. Dari 500 milyar anggaran IT yang dialokasikan pada tahun anggaran 2009, alokasi langsung terhadap pelatihan dianggarkan sebesar 1 milyar. (2) Persentase personil IT yang dilatih untuk menggunakan teknologi baru adalah 5\%. Setiap tahun Direktorat TTKI menganggarkan untuk mengadakan pelatihan penggunaan teknologi baru terhadap 5 dari total 100 staf mereka.

Tujuan strategis kedua yaitu keahlian personil IT dilakukan dengan mengukur piramida umur personil IT yang diambil dari pendalaman dokumen Sistem Informasi Kepegawaian Direktorat Pajak. Dengan asumsi bahwa usia produktif berada pada rentang 20-35 tahun, terdapat 93 dari 100 personil Direktorat TTKI berusia produktif. Dengan demikian dapat diambil kesimpulan bahwa piramida umur personil IT mendapatkan angka persentase sebesar $93 \%$.

Tujuan strategis ketiga adalah penelitian terhadap teknologi yang sedang berkembang. Untuk mengukur tingkat dukungan IT pada tujuan strategis ini menggunakan dua ukuran strategis. Terdapat dua hasil dari pengukuran terhadap dua ukuran strategis tersebut. (1) Persentase anggaran IT yang digunakan untuk penelitian adalah sebesar $0.2 \%$ dengan asumsi alokasi dana untuk penelitian diambil dari anggaran pelatihan. (2) Persentase personil IT yang ahli di bidang teknologi maju adalah 30\%. Ukuran strategis ini bertujuan untuk menghitung seberapa besar persentase personil IT yang memiliki keahlian di bidang teknologi maju, dengan asumsi bahwa yang dimaksud teknologi maju adalah penguasaan teknologi web based application, teknologi blade server, dan teknologi business intelligence. Hasil pengukuran IT Balanced Scorecard dirangkum ke dalam tabel V. 
TABEL V

HASIL PENGUKURAN IT BALANCED SCORECARD

\begin{tabular}{lc}
\hline \hline \multicolumn{1}{c}{ Perspektif } & Hasil \\
\hline Kontribusi Perusahaan & $49 \%$ \\
Orientasi Pengguna & $73.8 \%$ \\
Penyempurnaan Operasional & $68.3 \%$ \\
Orientasi Masa Depan & $25.6 \%$ \\
\hline \hline
\end{tabular}

Dari hasil pengukuran kontribusi terhadap perusahaan terdapat dua ukuran strategis penilaian yang perlu diperhatikan, yaitu pengendalian biaya dan persentase sumber daya terpakai antar unit. Pada pengendalian biaya, terdapat $10 \%$ proyek IT yang dikelola Direktorat TTKI pada tahun anggaran 2009 menggunakan alokasi dana lebih rendah daripada anggaran yang disediakan. Pada persentase sumber daya terpakai antar unit peneliti melihat banyaknya sumber daya printer yang tercatat sebagai asset pada rentang tahun 2000-2005. Banyaknya sumber daya printer yang tidak dapat digunakan secara bersama disebabkan oleh sifat pengadaan peralatan pada tahun anggaran tersebut belum menganggap penting penggunaan sumber daya printer secara bersama. Diperkirakan jika ukuran strategis dalam perspektif ini digali lebih dalam, terutama dengan kajian financial menggunakan metode Information Economics, akan meningkatkan persentase dukungan IT pada Direktorat TTKI. Berdasarkan data dari hasil penelitian, tingkat dukungan IT Direktorat TTKI pada perspektif ini memiliki angka rata-rata $49 \%$.

Pada persepektif orientasi pengguna, berdasarkan data yang diperoleh tingkat dukungan IT pada Direktorat TTKI didapatkan angka ratarata sebesar $73.8 \%$. Hasil pengukuran tingkat dukungan IT pada perspektif ini semuanya mencapai di atas $62 \%$. Hasil pengukuran terendah sebesar $62.2 \%$ terjadi pada pengukuran persentase proses otomatis terhadap proses manual.

Pada perspektif penyempurnaan operasional terdapat dua ukuran strategis yang perlu diperhatikan, yaitu frekuensi perawatan aplikasi dan rata-rata waktu perbaikan. Untuk ukuran strategis frekuensi perawatan aplikasi berdasarkan data hasil penelitian didapatkan rata-rata nilai yang menunjukan bahwa rata-rata frekuensi perawatan aplikasi dilakukan sebanyak satu kali pada tiap bulan. Angka rata-rata yang menyatakan tingkat dukungan IT pada Direktorat TTKI pada perspektif penyempurnaan operasional diperoleh sebesar $68.3 \%$.

Perspektif orientasi masa depan mendapat angka rata-rata terkecil di antara empat perspektif yang lain, yaitu sebesar $25.6 \%$. Nilai ini dikarenakan rendahnya anggaran IT untuk pelatihan dan penelitian yang dilakukan oleh Direktorat TTKI. Selain itu, pegawai juga merasa masih kurang dalam mendapatkan pelatihan untuk menggunakan IT yang baru. Berdasarkan dokumen Proyek IT pada tahun anggaran 2009, lebih dari $90 \%$ alokasi dana dibelanjakan untuk pembelian perangkat keras dan perangkat lunak penunjang yang baru. Sementara biaya pelatihan disisipkan ke dalam tiap proyek IT tersebut.

\section{Kesimpulan}

Berdasarkan penelitian terhadap pengukuran dukungan IT Direktorat TTKI pada Direktorat Jenderal Pajak maka dapat diambil beberapa kesimpulan. (1) Dari hasil penelitian dan dibandingkan dengan situasi sebenarnya pada Direktorat TTKI, dapat disimpulkan bahwa IT Balanced Scorecard dapat memberikan gambaran dalam pengukuran tingkat dukungan IT pada Direktorat TTKI, Direktorat Jenderal Pajak. (2) Tingkat dukungan IT pada Direktorat TTKI pada persepektif kontribusi perusahaan sebesar $49 \%$, perspektif orientasi pengguna sebesar $73.8 \%$, perspektif penyempurnaan organisasi sebesar $68.3 \%$, dan perspektif orientasi masa depan sebesar $25.6 \%$. Perspektif orientasi masa depan mendapatkan tingkat penilaian paling rendah, yang berarti bahwa persiapan IT dalam mengantisipasi kebutuhan Direktorat TTKI yang akan datang masih rendah.

Peneliti mengajukan beberapa rekomendasi terhadap Direktorat TTKI untuk meningkatkan tingkat dukungan IT di masa yang akan datang. Pertama, perlu adanya pengendalian anggaran IT yang lebih baik. Terdapat beberapa aspek yang memperoleh nilai pengukuran yang sangat rendah, terutama karena ketidaktepatan perkiraan anggaran IT. Tidak tepatnya perkiraan biaya disebabkan oleh tidak akuratnya data acuan yang digunakan oleh direktorat Transformasi Teknologi Komunikasi dan Informasi terutama pada perkiraan biaya perangkat keras. Yang harus dilakukan selanjutnya adalah dengan menggunakan e-procurement. Penggunaan database terpusat di dalam e-procurement diharapkan dapat meningkatkan tingkat akurasi perkiraan biaya terhadap harga perangkat yang sering dibelanjakan oleh Direktorat Jenderal Pajak terutama dalam proyek pengadaan IT. Tidak tepatnya antara perkiraan biaya dan penggunaan biaya dapat mengakibatkan penyerapan anggaran IT dinilai rendah. Hal ini akan berakibat langsung alokasi anggaran yang disetujui pada tahun anggaran selanjutnya hanya mendapatkan anggaran sebesar persentase penyerapan anggaran pada tahun berjalan.

Kedua, peningkatan pemakaian secara bersama sumber daya antar unit. Pemakaian secara bersama sumber daya IT masih perlu ditingkatkan agar dapat pula meningkatkan 
utilisasi penggunaan sumber daya tersebut dan sekaligus mengefisiensikan anggaran belanja IT. Pada ukuran strategis ini, peneliti merekomendasikan untuk memulai digunakan sumber daya printer yang memiliki kemampuan jaringan dan melatih para pengguna untuk menggunakan printer ini, lalu menarik kembali sumber daya printer yang tidak dapat digunakan bersama secara bertahap.

Ketiga, peningkatan frekuensi perawatan aplikasi dan kecepatan penyelesaian masalah IT. Hasil pengukuran terhadap efisiensi fungsi layanan masih menunjukkan nilai yang rendah terutama terkait perawatan aplikasi dan kinerja penyelesaian masalah IT. Peneliti merasa frekuensi pengecekan ini harus ditingkatkan menjadi satu kali tiap minggu atau empat kali setiap bulan dari satu kali dalam setiap bulan. Pada ukuran strategis rata-rata waktu perbaikan berdasarkan data hasil penelitian rata-rata personil IT membutuhkan waktu 1-2 jam untuk memperbaiki setiap kesalahan.

Sebagai bahan perbaikan, peneliti merekomendasikan selain meningkatkan kemampuan teknis staf IT, perlu adanya sebuah sistem Knowledge Management yang berfungsi untuk mencatat semua permasalahan IT dan solusinya. Dengan diterapkannya sistem Knowledge Management diharapkan tingkat penyelesaian sebuah masalah IT dapat dipersingkat. (4) Peningkatan anggaran untuk pelatihan dan penelitian. Hasil pengukuran terhadap penggunaan anggaran pelatihan dan penelitian masih menunjukkan hasil yang rendah. Hal ini disebabkan anggaran pelatihan dan penelitian masih menjadi satu dengan anggaran pengadaan.

Peneliti menyarankan agar dilakukan pemisahan anggaran penelitian dan pelatihan dari anggaran pengadaan untuk memperjelas dan mempermudah dalam mengukur seberapa besar dana yang digunakan untuk pelatihan dan penelitian khususnya penelitian dan pelatihan IT. Peneliti juga menyarankan perlu adanya peningkatan anggaran pelatihan dan penelitian untuk staf IT, agar para staf ini memiliki kompetensi dan penguasaan terhadap teknologi IS/IT yang berjalan dan pada masa yang akan datang pada Direktorat Jenderal Pajak. Selain itu, peneliti juga menyarankan adanya penelitian lebih lanjut yang dapat memberikan gambaran hubungan antara kesiapan kompetensi sumber daya manusia IT untuk kebutuhan yang akan datang dengan tingkat pencapaian tujuan strategis organisasi.

\section{Referensi}

[1] F. Purnomo, "Pengukuran Dukungan Divisi Teknologi Informasi terhadap Strategi Sebuah Lembaga Pendidikan dengan Menggunakan IT Balanced Scorecard Studi Kasus: Universitas Bina Nusantara," Ph.D Thesis, Magister of Information Technology, Universitas Indonesia, Indonesia, 2002.

[2] R. Robbi, "Penilaian Tingkat Kematangan Keselarasan Strategi Teknologi Informasi Terhadap Strategi Organisasi Studi Kasus POLDA Kalimantan Selatan," Ph.D Thesis, Magister of Information Technology, Universitas Indonesia, Indonesia, 2010.

[3] B. Kelana, "Pengukuran Kinerja Implementasi ASI TI berdasarkan tahap Akuisisi dan implementasi Cobit Frame Work dan IT Balanced Scorecard," Ph.D Thesis, Magister of Information Technology, Universitas Indonesia, Indonesia, 2004.

[4] R. Hartawan, "Integrasi IT Balanced Scorecard dan SIX Sigma untuk Meningkatkan Pengelolaan Divisi TI: Studi Kasus PT XYZ," Ph.D Thesis, Magister of Information Technology, Universitas Indonesia, Indonesia, 2005.

[5] A. Prasetya, "Analisis dan Pengukuran Kinerja Manajemen Pengembangan Aplikasi TI Perusahaan dengan Menggunakan IT BSC, COBIT dan IT-IL Studi Kasus: PT Bank Bukopin," Ph.D Thesis, Magister of Information Technology, Universitas Indonesia, Indonesia, 2007.

[6] J.I. Cash, F.W. McFarlan, \& J.L. McKenney, Corporate Management Systems Text and Cases, R. D. Irwin, 1983.

[7] W.V. Grembergen \& R.V. Bruggen, "Measuring and improving coporate information technology through the Balanced Scorecard" In European Conference on Information Technology, pp. 1-18, 1998.

[8] G.L. Dodaro, Measuring Performance and Demonstrating Results of Information Technology Investments, US GAO, http://www.gao.gov/special.pubs/ai98089.pd f, 1998, retrieved August 26, 2010

[9] W.V. Grembergen \& S.D. Haes, Measuring and improving coporate information technology through the Balanced Scorecard, http://www.isaca.org/Template.cfm?Section $=$ Home $\&$ CONTENTID=24171 \&TEMPLAT $\mathrm{E}=/$ ContentManagement/ContentDisplay.cf m, 2005, retrieved August 25, 2010 